\title{
Gamma-aminobutyric-acid-B receptor antibodies in limbic encephalitis with small cell lung cancer
}

\author{
Ke-Qin Liu, Sheng-Qiang Yan, Min Lou \\ Department of Neurology, The Second Affiliated Hospital of Zhejiang University, School of Medicine, Hangzhou 310009, Zhejiang, China.
}

\section{A B S T R A C T}

Encephalitis associated with antibodies to gamma-aminobutyric-acid B (GABA-B) is a subgroup of autoimmune synaptic encephalitis with typical features of limbic encephalitis and small cell lung cancer (SCLC). We report a case of anti-GABA-B receptor encephalitis in a 57-year-old man who presented with seizures, memory loss, and abnormal behavior. He developed partially neurological responses to immunotherapy, but refused comprehensive tumor screening. The symptoms were aggravated again 4 months later. Workup showed antibodies to GABA-B receptors and tumor screening revealed SCLC. It highlights the importance of early screening of underlying tumor and anti-tumor treatment in paraneoplastic cases.

Key words: Gamma-aminobutyric-acid-B receptor antibodies, limbic encephalitis, small cell lung cancer

\section{INTRODUCTION}

Encephalitis associated with antibodies to gamma-aminobutyric-acid B (GABA-B) receptors has been recognized as a subgroup of autoimmune synaptic encephalitis recently. ${ }^{[1]}$ It has been demonstrated that GABA-B receptors were engaged during rhythmic activity in the hippocampus and sculpted this activity. ${ }^{[2]}$ Correspondingly, anti-GABA-B encephalitis mostly presents with symptoms of limbic encephalitis (LE), which was characterized by memory loss, confusion, hallucinations, personality changes, and seizures. The GABA-B receptors are also distributed in the cerebral cortex, thalamic nuclei, cerebellum, and amygdala. ${ }^{[3]}$ The initial symptom presentation of cerebellum or brain stem were thus reported in some patients, such as rotational vertigo, ataxia, and opsoclonus. ${ }^{[4,5]}$

In nearly half of patients with anti-GABA-B encephalitis, the immune response occurs as a paraneoplastic event, most of which were small cell lung cancer (SCLC). Here, we report a case of a 57-year-old man who presented

\begin{tabular}{|l|l|}
\hline \multicolumn{2}{|c|}{ Access this article online } \\
\hline Quick Response Code: & \\
\hline & Website: \\
\hline & Www.nnjournal.net \\
& DOI: \\
\hline
\end{tabular}

with typical symptoms of LE and was finally found SCLC 5 months after onset.

\section{CASE REPORT}

A 57-year-old man was admitted to our hospital with recurrent generalized tonic-clonic seizure (GTCS), which is also called grand mal seizure, for 4 months and aggressive behavior, memory impairment, confusion for 4 days. Subsequent neurological examination revealed disorientation, lack of concentration and loss of memory, predominantly short-term memory. Past medical history was clean.

Blood cell count, general chemistry, thyroid function and tumor markers, including carcinoembryonic antigen, $\alpha$-fetoprotein, carbohydrate antigen-199 (CA199), CA125, CA242, cytokeratin-211 and neuron-specific enolase (NSE), were unrevealing. Cerebrospinal fluid (CSF) analysis (on day 3) detected an elevation of protein, count of white blood cells and glucose levels [Table 1]. Brain magnetic resonance imaging (MRI) revealed bilateral increased T2 signal in the medial temporal lobe [Figure 1]. Chest computed tomography (CT) revealed enlarged mediastinal lymph nodes.

The seizure was controlled after the administration of valproic acid (500 mg/day) and immunomodulating therapy with $40 \mathrm{mg}$ of methylprednisolone on

Corresponding Author: Prof. Min Lou, Department of Neurology, School of Medicine, The Second Affiliated Hospital of Zhejiang University, No. 88, Jiefang Road, Hangzhou 310009, Zhejiang, China. E-mail: loumingxc@vip.sina.com 
Table I: Clinical symptoms and images information before and after treatment

\begin{tabular}{|c|c|c|c|c|}
\hline Stage & Presenting symptoms & CSF & MRI & Tumor screening \\
\hline $\begin{array}{l}\text { First } \\
\text { admission }\end{array}$ & $\begin{array}{l}\text { GTCS, aggressive behavior, memory } \\
\text { impairment, confusion }\end{array}$ & $\begin{array}{l}\text { WBC } 12 / \mu \mathrm{L} \\
\text { Protein } 60.1 \mathrm{mg} / \mathrm{dL} \\
\text { Glc } 4.30 \mathrm{mmol} / \mathrm{L}\end{array}$ & $\begin{array}{l}\text { Bilateral increased T2 signal in } \\
\text { the medial temporal lobe }\end{array}$ & $\begin{array}{l}\text { Enlarged mediastina } \\
\text { lymph nodes }\end{array}$ \\
\hline $\begin{array}{l}\text { After } \\
\text { treatment }\end{array}$ & Mild memory impairment & - & $\begin{array}{l}\text { Mild increased T2 signal } \\
\text { (1-month outpatient follow-up) }\end{array}$ & - \\
\hline $\begin{array}{l}\text { Second } \\
\text { admission }\end{array}$ & $\begin{array}{l}\text { Aggressive behavior, distinct memory } \\
\text { impairment (milder than the first admission) }\end{array}$ & $\begin{array}{l}\text { WBC } 4 / \mu \mathrm{L} \\
\text { Protein } 40.2 \mathrm{mg} / \mathrm{dL} \\
\text { Glc } 3.63 \mathrm{mmol} / \mathrm{L}\end{array}$ & $\begin{array}{l}\text { Mild increased T2 signal } \\
\text { (severer than the follow-up image) }\end{array}$ & SCLC \\
\hline
\end{tabular}

CSF: cerebrospinal fluid, MRI: magnetic resonance imaging, GTCS: generalized tonic-clonic seizure, WBC: white blood cell, Glc: glucose, SCLC: small cell lung cancer


Figure 1: Brain magnetic resonance imaging screens in anti-gammaaminobutyric-acid B receptor encephalitis: (a) revealed bilateral increased T2 signal in the medial temporal lobe at the first admission; (b) showed milder increased T2 signal 1 months after the first discharge; (c) revealed the lesion worsen again at the second admission

admission. A repeated brain MRI was performed on day 20 and revealed even severer bilateral fluid-attenuated inversion recovery (FLAIR) and T2 hyperintensity in the medial temporal lobe. Therefore, intravenous immunoglobulins (IVIg) (400 mg/kg/day) was administered for 5 days on day 20. The patient developed significant improvement of limbic dysfunction during the IVIg therapy. Although no occupying lesion was found in lung, we suggested further tumor screening including biopsy of mediastinal lymph nodes and fluorodeoxyglucose positron emission tomography. However, the patient refused further extensive screen for underlying tumor and was discharged 25 days after admission, with full recovery of behavior and mental status, and partially improvement of memory impairment. One month after discharge, the follow-up brain MRI showed the lesion in remission [Figure 1].

The patients remained no recurrence of seizure and stable LE symptom during nearly 3 months follow-up. However, he was found collapsed 4 months after discharge, with subsequent recurrence of the abnormal behavior, disorientation, and worsening of memory impairment. Brain MRI revealed distinct lesions again [Figure 1]. CSF analysis revealed normal levels of protein, white blood, and glucose [Table 1]. Results for central nervous system (CNS) autoantibodies testing revealed CSF antibodies to GABA-B receptor (IgG 1:100). Other tested CNS autoantibodies, including anti-leucine-rich glioma inactivated-1 (LGI1) receptor, anti-contactin-associated protein-like 2 receptor, anti-N-methyl-D-aspartate receptor, anti- $\alpha$-amino-3-h ydroxy-5-methyl-4-isoxazolepropionic acid receptor, rheumatological autoantibodies, thyroid function tests, anti-thyroglobulin and thyroid peroxidase antibodies were all negative. Tumor marker tests revealed elevated CA125 of $35.2 \mathrm{U} / \mathrm{mL}$ and mild elevated of NSE of $25.7 \mathrm{ng} / \mathrm{mL}$. A repeated chest CT showed a mass in right hilus pulmonis, which was finally confirmed to be SCLC by biopsy. Unfortunately, the patient and his carers refused further immunomodulating or antineoplastic treatments. He was discharged with memory impairment, which was persisted after another 3 months follow-up.

\section{DISCUSSION}

The misdiagnosis rate of anti-GABA-B receptor encephalitis is high since autoantibodies tests were still not popularized in many countries. Most recently, case serials of patients with anti-GABA-B receptor encephalitis emphasized the typical triad of clinical presentation, including memory alternation, seizures, and SCLC. ${ }^{[6]}$ There are numbers of SCLC-associated onconeural antibodies, including $\mathrm{Hu}$, amphiphysin, and collapsin response-mediator protein (CV2). Anti-GABA-B receptor antibodies may be detected in patients with LE associated with SCLC who are seronegative for other onconeural antibodies. ${ }^{[7]}$ The mechanism of SCLC-associated autoimmune responses remains to be elucidated. It may be related to abnormal self-antigen expression in tumor cells, or the antigenic protein might be mutated or modified to those foreign to the immune system. Neurological symptoms often present before the cancer becomes symptomatic, suggesting the importance of early detection and diagnosis of SCLC. The paraneoplastic cases with anti-GABA-B encephalitis, particularly SCLC, presented at an older age range from 53 to 75 years old, and had male predominance. ${ }^{[1,4]}$ Paraneoplastic cases seemed to have higher titers antibodies, mostly higher than 1:100 (IgG) in CSF. ${ }^{[1,4,8]}$ 
The neuroimaging characteristics of anti-GABA-B encephalitis were nonspecific, nearly half of which might present unilateral or bilateral FLAIR and T2 hyperintensity in the medial temporal lobe, sometimes in cerebellum or brain stem which corresponded to the symptoms. Previous reports found that the severity of clinical symptoms was not associated with the lesion size on brain image, nor was the presence or absence of underlying tumors. ${ }^{[1]}$

Regardless of being paraneoplastic or not, most of the patients developed substantial or full neurological responses to immunotherapy, including steroids, IVIg, and plasma exchange. In paraneoplastic cases, however, patients might achieve neurological improvement with successful anti-tumor treatments even without immunotherapy. ${ }^{[4]}$ In addition, the duration of disease and clinical outcomes varied depending on the presence or absence of SCLC. In our case, the clinical and neuroimaging characteristics recurred without detection and treatment of SCLC, which emphasized the importance of early identification of underlying tumors.

In conclusion, anti-GABA-B receptor encephalitis is a potentially treatable disorder that should be diagnosed by autoantibodies tests. Aggressive immunotherapy is often effective, but anti-tumor therapy is also pivotal for the neurological recovery and long-term outcomes of patients with the paraneoplastic event. This case report joined to the previously reported description of this paraneoplastic syndrome,,$^{[1,4]}$ to delineate the importance of early diagnosis for the prognosis and management.

\section{REFERENCES}

1. Lancaster E, Lai M, Peng X, Hughes E, Constantinescu R, Raizer J, Friedman D, Skeen MB, Grisold W, Kimura A, Ohta K, lizuka T, Guzman M, Graus F, Moss SJ, Balice-Gordon R, Dalmau J. Antibodies to the GABA (B) receptor in limbic encephalitis with seizures: case series and characterisation of the antigen. Lancet Neurol 2010;9:67-76.

2. Scanziani M. GABA spillover activates postsynaptic GABA (B) receptors to control rhythmic hippocampal activity. Neuron 2000;25:673-81.

3. Benarroch EE. GABA receptors: structure, functions, and clinical implications. Neurology 2012;78:578-84.

4. Höftberger R, Titulaer MJ, Sabater L, Dome B, Rózsás A, Hegedus B Hoda MA, Laszlo V, Ankersmit HJ, Harms L, Boyero S, de Felipe A, Saiz A, Dalmau J, Graus F. Encephalitis and GABAB receptor antibodies: novel findings in a new case series of 20 patients. Neurology 2013;81:1500-6.

5. Mundiyanapurath S, Jarius S, Probst C, Stöcker W, Wildemann B Bösel J. GABA-B-receptor antibodies in paraneoplastic brainstem encephalitis. J Neuroimmunol 2013;259:88-91.

6. Kim TJ, Lee ST, Shin JW, Moon J, Lim JA, Byun JI, Shin YW, Lee KJ, Jung KH, Kim YS, Park KI, Chu K, Lee SK. Clinical manifestations and outcomes of the treatment of patients with GABAB encephalitis. J Neuroimmunol 2014;270:45-50.

7. Boronat A, Sabater L, Saiz A, Dalmau J, Graus F. GABA (B) receptor antibodies in limbic encephalitis and anti-GAD-associated neurologic disorders. Neurology 2011;76:795-800.

8. Dogan Onugoren M, Deuretzbacher D, Haensch CA, Hagedorn HJ Halve S, Isenmann S, Kramme C, Lohner H, Melzer N, Monotti R Presslauer S, Schäbitz WR, Steffanoni S, Stoeck K, Strittmatter M Stögbauer F, Trinka E, von Oertzen TJ, Wiendl H, Woermann FG, Bien CG. Limbic encephalitis due to GABAB and AMPA receptor antibodies: a case series. J Neurol Neurosurg Psychiatry 2014; [doi: 10.1136/jnnp-2014-308814].

Cite this article as: Liu KQ, Yan SQ, Lou M. Gamma-aminobutyric-acid-B receptor antibodies in limbic encephalitis with small cell lung cancer. Neuroimmunol Neuroinflammation 2015;2(3):187-9.

Source of Support: Nil. Conflict of Interest: No.

Received: 28-02-2015; Accepted: 23-04-2015 